\title{
Pancreatic panniculitis
}

\author{
Takamasa Ito, Reine Moriuchi, Kazuhiro Kikuchi, Satoko Shimizu
}

Sapporo City General Hospital, Sapporo, Japan

\section{Correspondence to}

Dr Takamasa Ito,

takamasa0794@yahoo.co.jp

Accepted 9 January 2015
CrossMark

To cite: Ito T, Moriuchi $R$, Kikuchi K, et al. BMJ Case Rep Published online: [please include Day Month Year] doi:10.1136/bcr-2014206980

\section{DESCRIPTION}

An 86-year-old woman was admitted to our hospital with a 1-month history of painful red nodules on both lower legs. She had no significant medical or medication history. On physical examination, multiple painful red nodules, up to $3 \mathrm{~cm}$ in diameter, were noted on her legs (figure 1). Histopathological examination showed lobular panniculitis with foci of necrosis, nuclear debris, and foam and ghost-like cells, characterised by anucleated adipocytes with a partially digested shadowy cell membrane (figures 2 and 3). The serum lipase level was $870 \mathrm{U} / \mathrm{L}$ (reference range, 0-160). A CT image revealed peripancreatic inflammation, a large fluid collection in the left side of the abdomen consistent with a pancreatic pseudocyst, and a $40 \mathrm{~mm}$ mass in the head of the pancreas with the appearances of a pancreatic head tumour. A diagnosis of pancreatic panniculitis associated with carcinoma of the head of pancreas was made.

The patient was treated with ulinastatin (a trypsin inhibitor) and intravenous fluid hydration. The skin eruption resolved within 2 weeks but the pancreatic mass rapidly progressed and the patient died 3 weeks after the diagnosis was made.

Pancreatic panniculitis is a rare complication of pancreatic diseases such as pancreatitis and pancreatic cancer. Excessive pancreatic enzyme may be released causing fat necrosis and the formation of subcutaneous nodules in the lower extremities. The diagnosis of panniculitis can lead the clinician to investigate for the presence of pancreatic pathology and institute appropriate treatment. ${ }^{12}$

The presence of pancreatic panniculitis should alert the clinician to potentially significant underlying pathology and in patients where atypical red, nodular lesions on the lower extremities are detected, potentially significant pancreatic pathology should be considered.

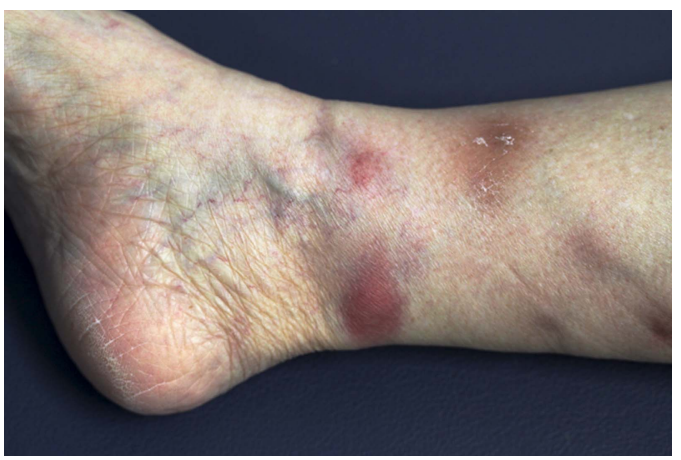

Figure 1 Multiple painful red nodules up to $3 \mathrm{~cm}$ in diameter on the lower legs.

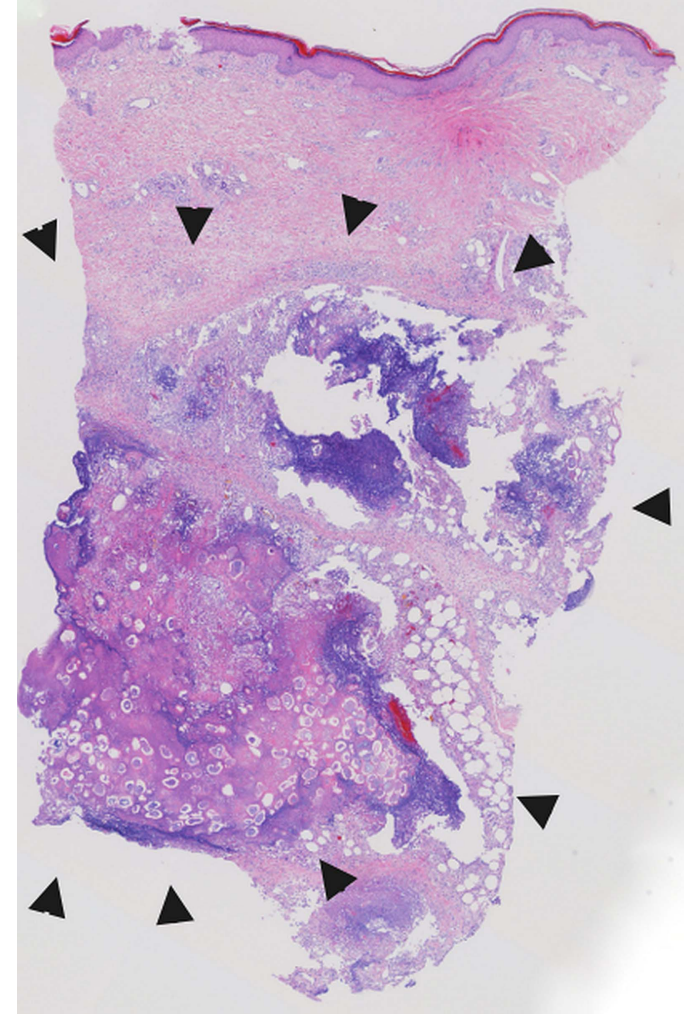

Figure 2 Lobular panniculitis with foci of necrosis, nuclear debris and foam $(\mathrm{H} \& \mathrm{E}$, original magnification $\times 20)$.

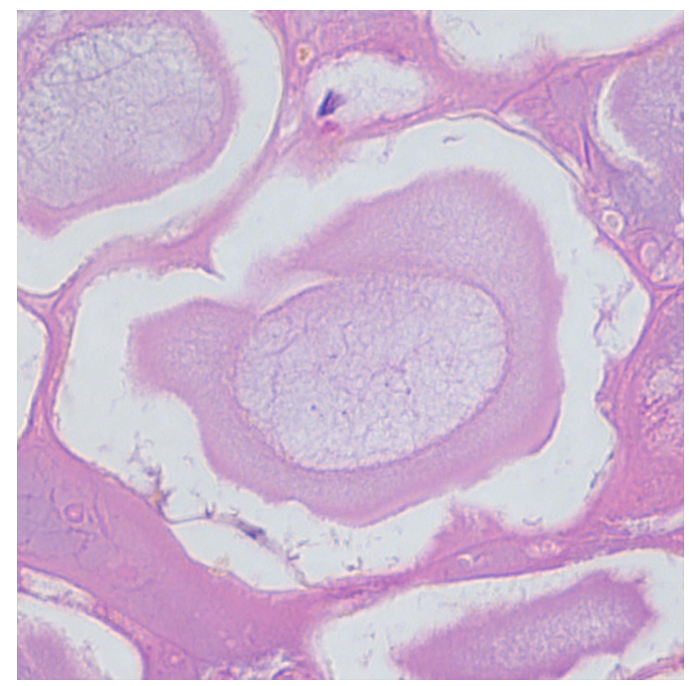

Figure 3 Ghost-like cells ( $H \& E$, original magnification $\times 400)$. 


\section{Learning points}

Pancreatic panniculitis develops in the setting of pancreatic disease, especially pancreatitis.

- The presence of widespread and persistent red painful nodules consistent with panniculitis on lower extremities should trigger clinicians to undertake investigations of the pancreas and the coexistence of a pancreatic carcinoma should be considered.
Competing interests None.

Patient consent Obtained.

Provenance and peer review Not commissioned; externally peer reviewed.

\section{REFERENCES}

1 Tran $\mathrm{KT}$, Hughes $\mathrm{S}$, Cockerell $\mathrm{CJ}$, et al. Tender erythematous plaques on the legs. Pancreatic panniculitis (PP). Clin Exp Dermatol 2010;35:e65-6.

2 Rani M, Kaka A. Lobular panniculitis. N Engl J Med 2013;368:465.

Copyright 2015 BMJ Publishing Group. All rights reserved. For permission to reuse any of this content visit http://group.bmj.com/group/rights-licensing/permissions.

BMJ Case Report Fellows may re-use this article for personal use and teaching without any further permission.

Become a Fellow of BMJ Case Reports today and you can:

- Submit as many cases as you like

- Enjoy fast sympathetic peer review and rapid publication of accepted articles

- Access all the published articles

- Re-use any of the published material for personal use and teaching without further permission

For information on Institutional Fellowships contact consortiasales@bmjgroup.com

Visit casereports.bmj.com for more articles like this and to become a Fellow 